AGH DRILLING, OIL, GAS • Vol. $34 \cdot$ No. $2 \cdot 2017$

http://dx.doi.org/10.7494/drill.2017.34.2.335

\author{
Marcin Kremieniewski*, Stanisław Stryczek**, Rafał Wiśniowski**, \\ Marcin Rzepka*, Andrzej Gonet**
}

\title{
INFLUENCE OF BENTONITE ADDITION ON PARAMETERS OF FRESH AND HARDENED CEMENT SLURRY***
}

\section{INTRODUCTION}

Sealing slurries and the resulting hardened slurries used for sealing the casing should meet respective standards. The parameters of fresh and resulting hardened cement sheath are modified with a variety of additives and admixtures. Last years have seen a growing interest in the realization of directional and horizontal wells. The parameters of slurries for this type of wellbores should be selected more strictly than in the case of vertical wells $[1,2,18]$. It should be stressed that the properties of each cement slurry mainly depends on the geologic-technical conditions in a well, where the slurry is bonding and the hardened cement sheath is formed. For this reason the influence of these additives and admixtures should be determined, not only on selected (modified) properties of the cement slurry, but also a complex analysis of all parameters in view of the applied additive. The analysis of particular technological parameters of cement slurry is very important because a tan early stage one can detect possible disturbances in the parameters of the designed composition of cement slurry [17]. It is very important because the possible complications are connected

\footnotetext{
* Oil and Gas Institute - National Research Institute

** AGH University of Science and Technology

*** Paper realized on the basis of the research work Analysis of possibility of improving the sedimentation stability of cement slurries - work of OGI - NRI on the order of the Ministry of Science and Higher Education, archival No.: DK-4100/36/16, order No.: 36/KW/16. Work realized at the Department of Drilling and Geoengineering, Faculty of Drilling, Oil and Gas AGH UST within the Statutory Research Program No. 11.11.190.555 WP2
} 
with huge difficulties in the liquidation of, e.g. exhalations or outflows of reservoir medium from the space between and beyond pipes. What is more, the cost of cementing up the wellbore is very high. For this reason the detailed analysis of impact of a single additive should not be omitted in elaborations and scientific publications.

\section{ROLE OF BENTONITE IN CEMENT SLURRIES}

Owing to the varying geological-technical conditions in the wellbore, appropriate additives have to be involved to produce a slurry which would have properties adjusted to the casing cementing project. One of such additives is bentonite, commonly known as montmorillonite [14]. This additive is presently applied in the cement slurry technology because of its ability to regulate numerous parameters. It is fine grained thanks to which can penetrate the filtration cake between the cement particles and eventually lower the filtration of the slurry. Clays and bentonites are composites of made of components building one or more clayey materials. The assume the form of hydrated aluminum silicate of filitosilicate group [6,11]. The most popular filler of this group of materials is bentonite, which contains at least $85 \%$ of mineral clays commonly called montmorillonite. Bentonite may expand its original volume several times, when mixed with water. The elastic viscosity, yield point and structural strength responsible for maintaining the solid phase, considerably increase. For this reason the use of bentonite is very favorable from the point of view of sedimentation stability of the slurry $[3,4,5,7]$. Because of the ability to absorb large quantities of water this additive causes homogenization of cement slurry and so prevents delamination of fractions of various weight. This is very important for designing slurries used for sealing of directional and horizontal wells, where the sedimentation stability is particularly important. Owing to the very dense structure of working water, bentonite is also used for designing lower density slurries. The presence of lower density additives, e.g. microsphere may cause delamination of slurry as a result of which light microsphere fractions will float on the surface of the prepared slurry. Bentonite addition to work water increases the rheological parameters of the cement slurry thanks to which the liquid slurry becomes homogeneous and the cement sheath obtains a uniform structure after the slurry hardens $[9,12,13]$. Bentonite is also used as a filler thanks to which smaller quantities of cement can be applied. Recipes of this type can be used for obtaining a very light slurry of high water/cement ratio $[8,11]$. Another design condition for this type of slurries is the cost factor. In this case the physicochemical conditions are ignored and they get poor because of the increased water/cement ratio. When designing a slurry (depending 
on the required properties) up to $20 \%\left(\right.$ bwoc $\left.^{1}\right)$ of bentonite is added. The analysis of the literature $[11,15,16]$ reveals that the concentrations above $6 \%$ may necessitate using of a plastifier to lower the viscosity and structural strength. According to $\mathrm{API}^{2}$ standard, the working water should be increased in the slurry by $5.3 \%$ per each $1 \%$ (bwoc) of bentonite for all cement classes. The increase of bentonite addition in the cement slurry results in the lowering of slurry density with the simultaneous increase of rheological parameters and weakening of mechanical parameters $[11,13]$. The influence of bentonite on the compression of hardened cement slurry is presented in Figure 1. According to the obtained data $[10,11]$ the use of bentonite in cement slurry may result in lower permeability which is not favorable in a situation of contact with sulfate and corrosive waters.

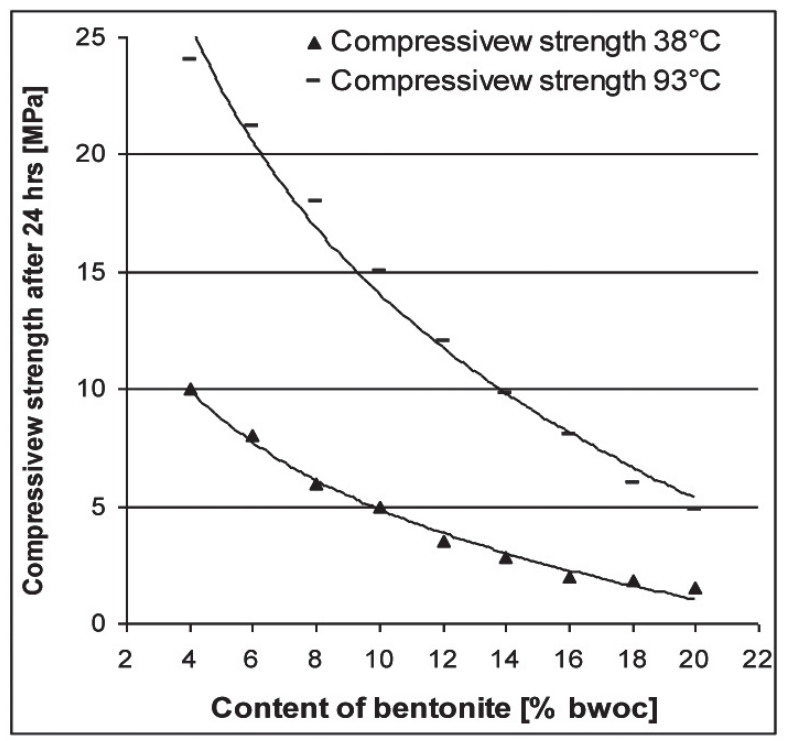

Fig. 1. Influence of bentonite addition on compressive strength of exemplary slurry

Literature abounds in partial results of bentonite impact on the parameters of slurry; besides this is a (simple) slurry containing only cement and water. Therefore an analysis was performed to see the impact of bentonite on parameters of slurries presently used in industry and which contain a few to ten or so various modifiers, as presented further in this paper.

1 Bwoc - by weight of cement

2 API - American Petroleum Institute 


\section{INVESTIGATIONS}

Analyses aimed at determining the influence of bentonite on the parameters of fresh cement slurry were performed at the Laboratory of Sealing Slurries OGI-NRI in line with standards: PN-85/G-02320 Cements and sealing slurries for cementing in wellbores; PN-EN 10426-2 Oil and gas industry. Cements and materials for cementing wells. Part 2: Analyses of drilling cements and API SPEC 10 Specification for materials and testing for well cements.

The presented investigation consisted of analyses of impact of bentonite on parameters of cement slurry.

For determining the effect of bentonite on parameters of cement slurry and the resulting cement sheath in the wellbore, eight slurry compositions were analyzed. For reference recipes were performed for comparison's sake. Four modified slurries contained bentonite. The influence of bentonite on the parameters of slurry in a possibly broad range of wellbore conditions was analyzed for temperatures $30^{\circ} \mathrm{C}, 50^{\circ} \mathrm{C}, 70^{\circ} \mathrm{C}$ and $90^{\circ} \mathrm{C}$, and the relating pressures $5 \mathrm{MPa}, 18 \mathrm{MPa}, 25 \mathrm{MPa}$ and $35 \mathrm{MPa}$, respectively. Natural sodium bentonite from Zębiec was used in the tests. Drilling cement G HSR (used in industry) was used as a binder. Portland cement CEM I 32,5R was applied in shallow wells of low downhole temperatures and pressures. During realization of the cycle of tests all recipes contained cement G HSR to eliminate discrepancies among results stemming from the use of various types of binder. For the sake of sealing up the matrix of the cement sheath, a $20 \%$ microcement admixture was applied in all recipes. A constant water/cement ratio of 0.50 was assumed; only in the recipe designed for wellbore temperature of $70^{\circ} \mathrm{C}$ and pressure $25 \mathrm{MPa}$ the ratio equaled to 0.57 . The assumed content of antifiltration coefficient and swelling agent totaled to $0.2 \%$ bwoc and $0.3 \%$ bwoc (Tab. 1). Constant quantity of latex $(10 \%$ bwoc) and latex stabilizer ( $1 \%$ bwoc) were admixed. The slurries were based on $3 \%$ salt content in the working water $\left(\right.$ bwow $\left.^{3}\right)$. The defoamer, liquefier, accelerating agent and retarder were added in quantities presented in Table 1. A constant quantity of bentonite was used, i.e. $0.5 \%$ (bwow) and $0.3 \%$ (bwow) of bentonite for a slurry to be used in a wellbore of a temperature $90^{\circ} \mathrm{C}$ and pressure $35 \mathrm{MPa}$. The measured quantity of bentonite was mixed with working water prior to the slurry components. These criteria and the mixing proportion were used for working out four reference recipes and four modified recipes, on the basis of which the influence of bentonite on parameters of slurry could be determined for particular temperatures. Detailed quantities of components are given in Table 1.

The analysis of the obtained results shows to the lowering of density of slurries after adding bentonite as compared to the basic slurries (Fig. 2 and Tab. 2). In the slurry designed for a wellbore with temperature $70^{\circ} \mathrm{C}$ and pressure $35 \mathrm{MPa}$, where water/cement ratio was higher $(\mathrm{w} / \mathrm{c}=0.57)$ the density of slurry was not observed to drop after adding bentonite.

3 Bwow - by weight of water 
Table 1

Recipes of cement slurries for wellbore conditions

Binder: cement G HSR $=100 \%$, microcement $20.0 \%$

\begin{tabular}{|c|c|c|c|c|c|c|c|c|c|c|c|c|}
\hline No. & $\begin{array}{c}\text { Composition } \\
\text { No. } \\
\text { Factor }(\mathrm{w} / \mathrm{c})\end{array}$ & 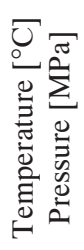 & 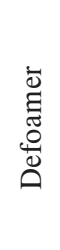 & 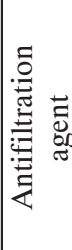 & 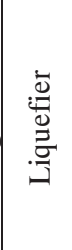 & 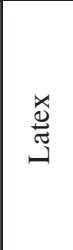 & 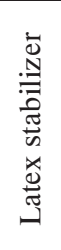 & 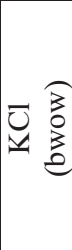 & 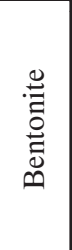 & 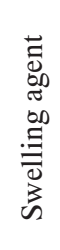 & $\tilde{U}^{N}$ & 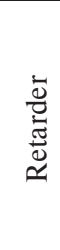 \\
\hline 1. & $\begin{array}{c}\text { No. } 1 \\
\mathrm{w} / \mathrm{c}=0.50\end{array}$ & \multirow{2}{*}{$\dot{O}_{0} \sum_{i}^{\pi}$} & 0.3 & 0.20 & 0.20 & 10.0 & 1.0 & 3.0 & - & 0.3 & 4.0 & - \\
\hline 2. & $\begin{array}{c}\text { No. } 2 \\
\mathrm{w} / \mathrm{c}=0.50\end{array}$ & & 0.3 & 0.20 & 0.20 & 10.0 & 1.0 & 3.0 & 0.50 & 0.3 & 2.0 & - \\
\hline 3. & $\begin{array}{c}\text { No. } 3 \\
\mathrm{w} / \mathrm{c}=0.50\end{array}$ & \multirow{2}{*}{$\begin{array}{l}\cup \\
0 \\
0 \\
i n\end{array}$} & 0.3 & 0.20 & 0.10 & 10.0 & 1.0 & 3.0 & - & 0.3 & - & 0.10 \\
\hline 4. & $\begin{array}{c}\text { No. } 4 \\
w / c=0.50\end{array}$ & & 0.3 & 0.20 & 0.10 & 10.0 & 1.0 & 3.0 & 0.50 & 0.3 & - & 0.10 \\
\hline 5 & $\begin{array}{c}\text { No. } 5 \\
\mathrm{w} / \mathrm{c}=0.57\end{array}$ & \multirow{2}{*}{ 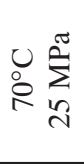 } & 0.4 & 0.20 & 0.20 & 10.0 & 1.0 & 3.0 & 0 & 0.3 & - & 0.05 \\
\hline 6. & $\begin{array}{c}\text { No. } 6 \\
w / c=0.57\end{array}$ & & 0.4 & 0.20 & 0.20 & 10.0 & 1.0 & 3.0 & 0.50 & 0.3 & - & 0.05 \\
\hline 7. & $\begin{array}{c}\text { No. } 7 \\
w / c=0.50\end{array}$ & \multirow{2}{*}{ 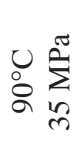 } & 0.5 & 0.20 & 0.25 & 10.0 & 1.0 & 3.0 & - & 0.3 & - & 0.25 \\
\hline 8. & $\begin{array}{c}\text { No. } 8 \\
w / c=0.50\end{array}$ & & 0.5 & 0.20 & 0.25 & 10.0 & 1.0 & 3.0 & 0.30 & 0.3 & - & 0.25 \\
\hline
\end{tabular}

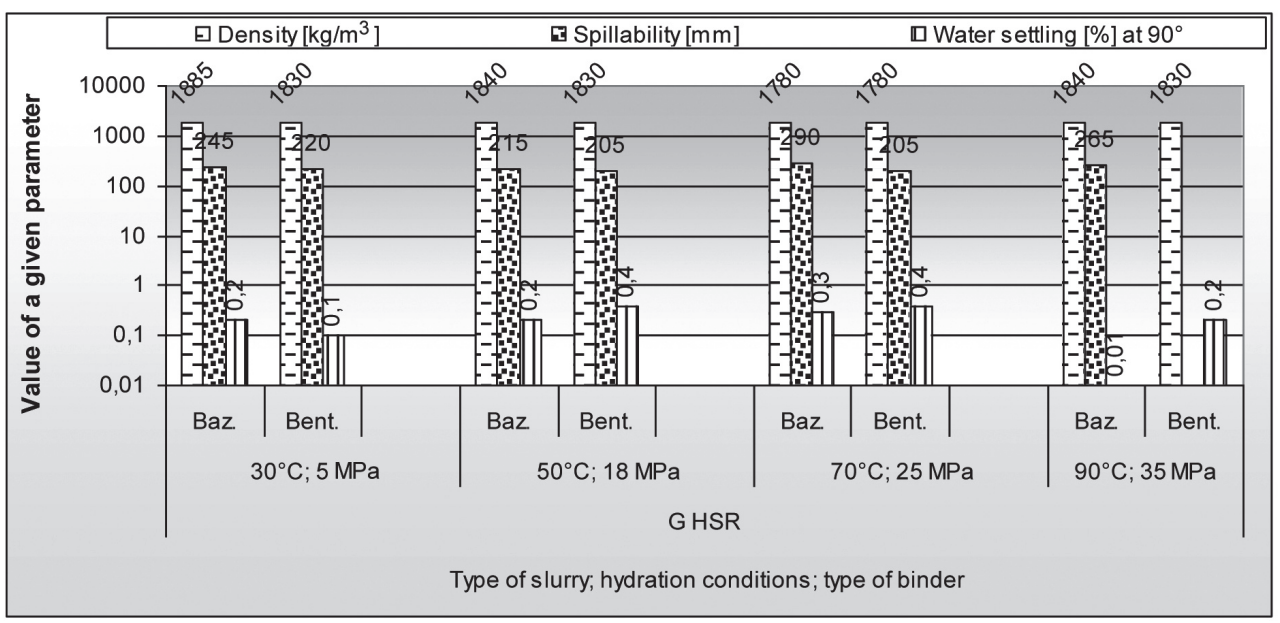

Fig. 2. Results of analyses of spillability density and settling of water for fresh cement slurries 


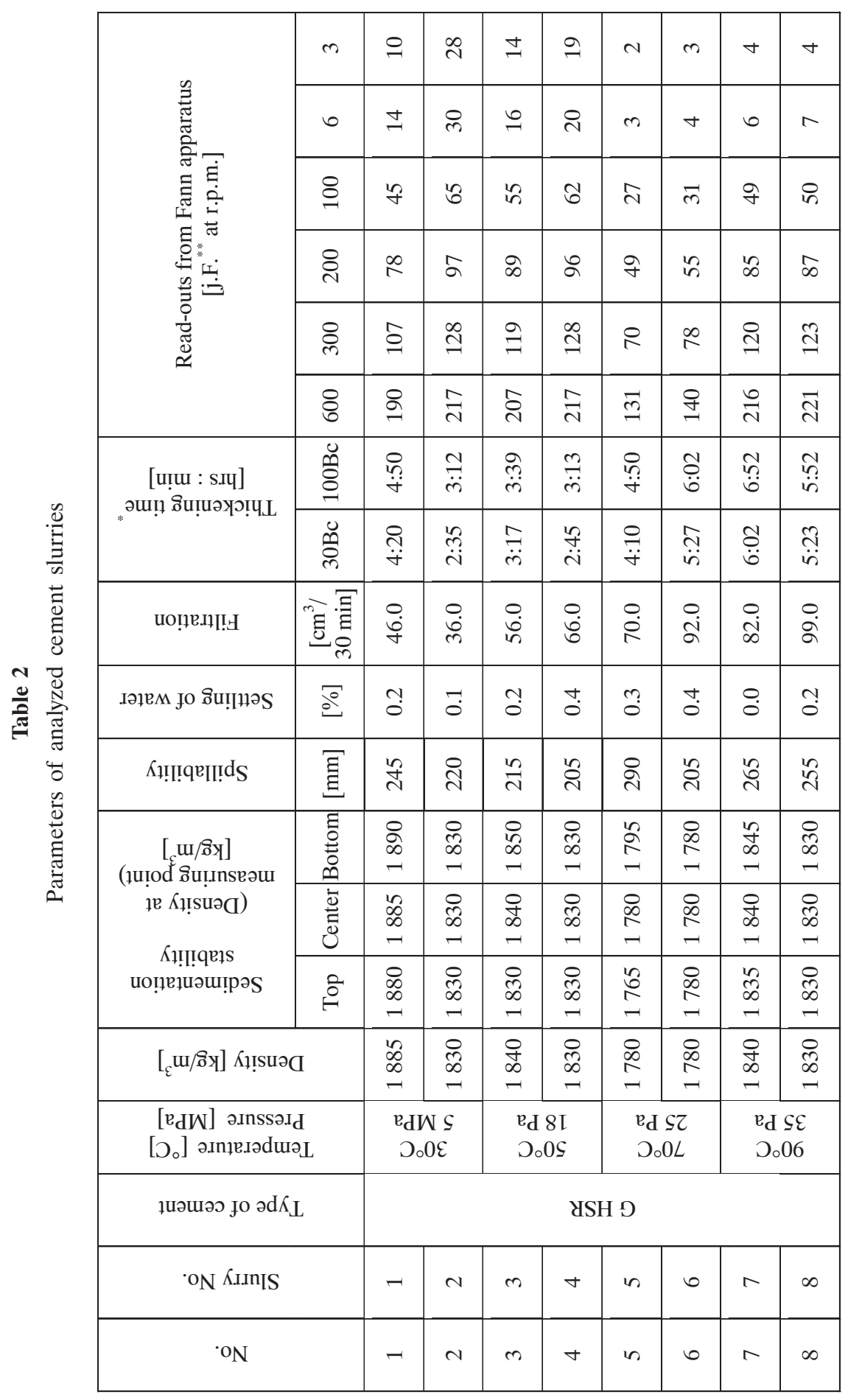

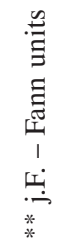

$\cdot \exists \cdot \exists$ 우용

베 \| $\|$

荧

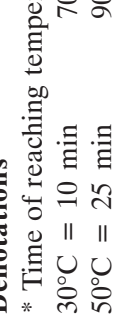


The sedimentation stability of bentonite slurry considerably improved as compared to the slurries without bentonite admixture. Density values at particular measuring points during the tests on the sedimentation column are presented in Table 2 and Figure 4. A density difference in Figure 5 was presented to visualize the improvement of sedimentation stability. The density difference between the top and central, and between central and bottom measuring point of reference slurries range from $5 \mathrm{~kg} / \mathrm{m}^{3}$ to $15 \mathrm{~kg} / \mathrm{m}^{3}$. After using bentonite the slurry revealed a homogeneous structure, with uniform density at all measuring points (top, central and bottom part of the measuring column).

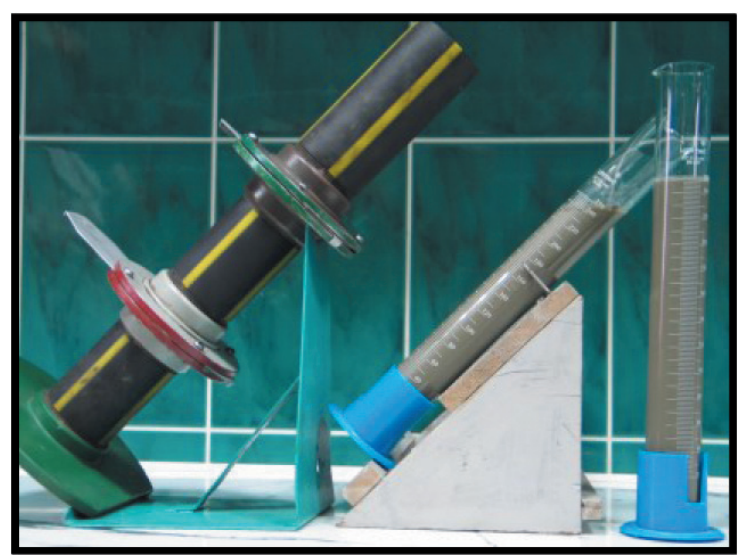

Fig. 3. Stand for determining sedimentation stability of cement slurry and settling of water (left: sedimentation column, right: settling cylinders)

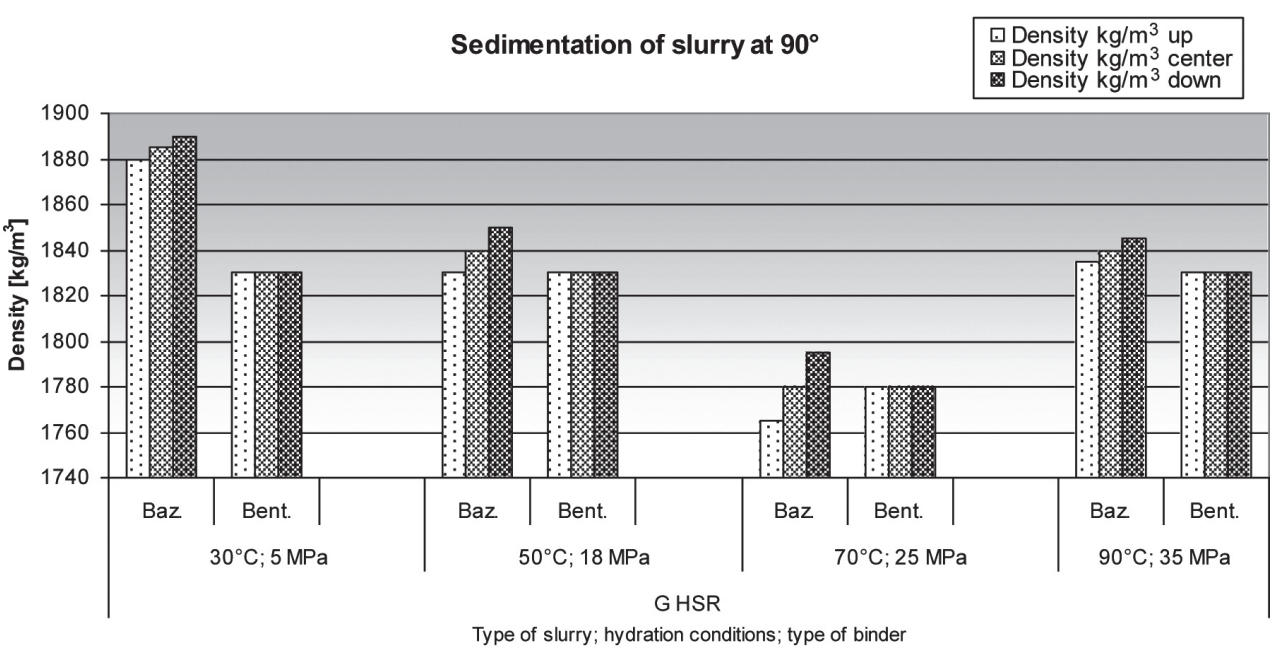

Fig. 4. Density of slurry in particular measuring points of sedimentation column 


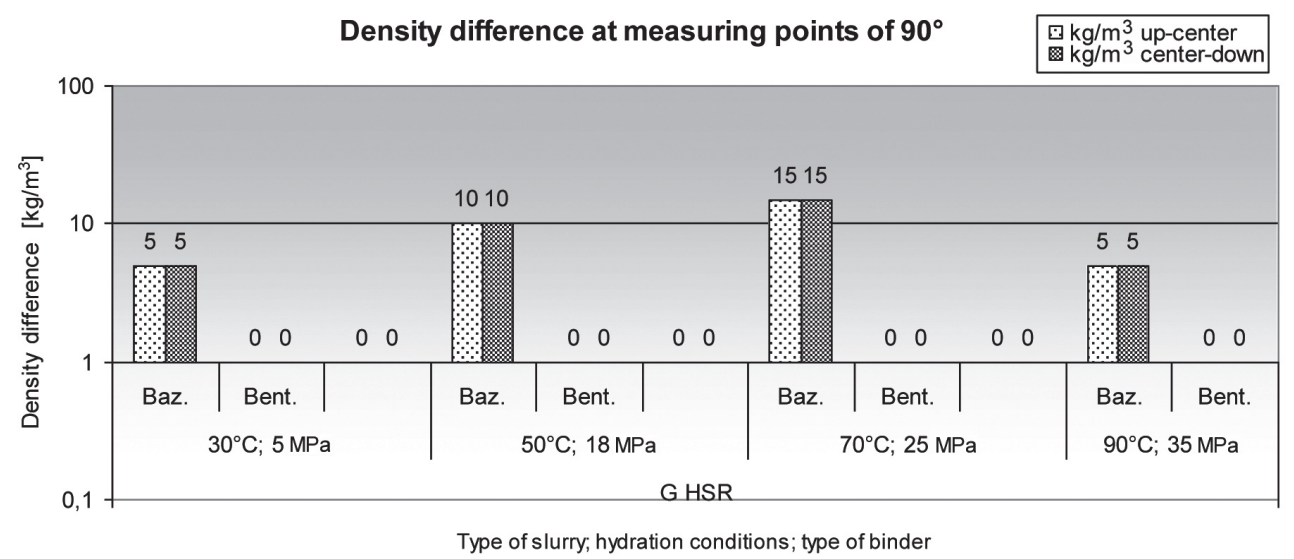

Fig. 5. Comparison of density differences at particular measuring points of sedimentation column (difference between top and central part, and central and bottom part of the column)

The use of bentonite also resulted in lower spillability; the highest reduction of this parameter was observed in a slurry having the highest water/cement ratio (slurry No. 6 in Tab. 2), where the spillability totaled to $205 \mathrm{~mm}$ (in the reference slurry for this recipe the spillability equaled to $290 \mathrm{~mm}$ ).

The analysis of water settling reveals that this parameter lowers only in slurry No. 2 (settlement $0.1 \%$ ) as compared to the reference slurry, i.e. $0.2 \%$. The successive recipes had an increasing tendency of water settlement (Tab. 2 and Fig. 2). The lowering of water settlement in slurry 2 as compared to other slurries can be explained by the participation of montmorillonite present in bentonite, causing a higher water demand, with addition of strongly hygroscopic calcium chloride used for shortening the time of bonding. The remaining recipes which do not contain $\mathrm{CaCl}_{2}$ show a comparable increasing tendency of water settlement values.

Analogous behavior of slurry as that of water settlement was observed during the analysis of slurry filtration values. Only in slurry No. 2, containing bentonite, the filtration lowered to $36 \mathrm{~cm}^{3} / 30 \mathrm{~min}$ as compared to the reference slurry (filtration $46 \mathrm{~cm}^{3} / 30 \mathrm{~min}$ ). Also in this case we may assume the synergy of montmorillonite and calcium chloride, which is amplified by the increased temperature in the filtration press. In the remaining cases, after adding bentonite the filtration of slurries was higher than in the reference slurries (Tab. 2).

The analysis of bentonite as an additive revealed that the time of thickening of cement slurry shortened - both at the beginning of thickening $\left(30 \mathrm{Bc}^{4}\right)$ and at the end of thickening $(100 \mathrm{Bc})$. The above effect was obtained for all recipes. The obtained results are presented in Table 2 and Figure 6.

$4 \mathrm{Bc}$ - unit of time of thickening of cement slurry while taking measurements in a consistmeter (Bearden unit) 


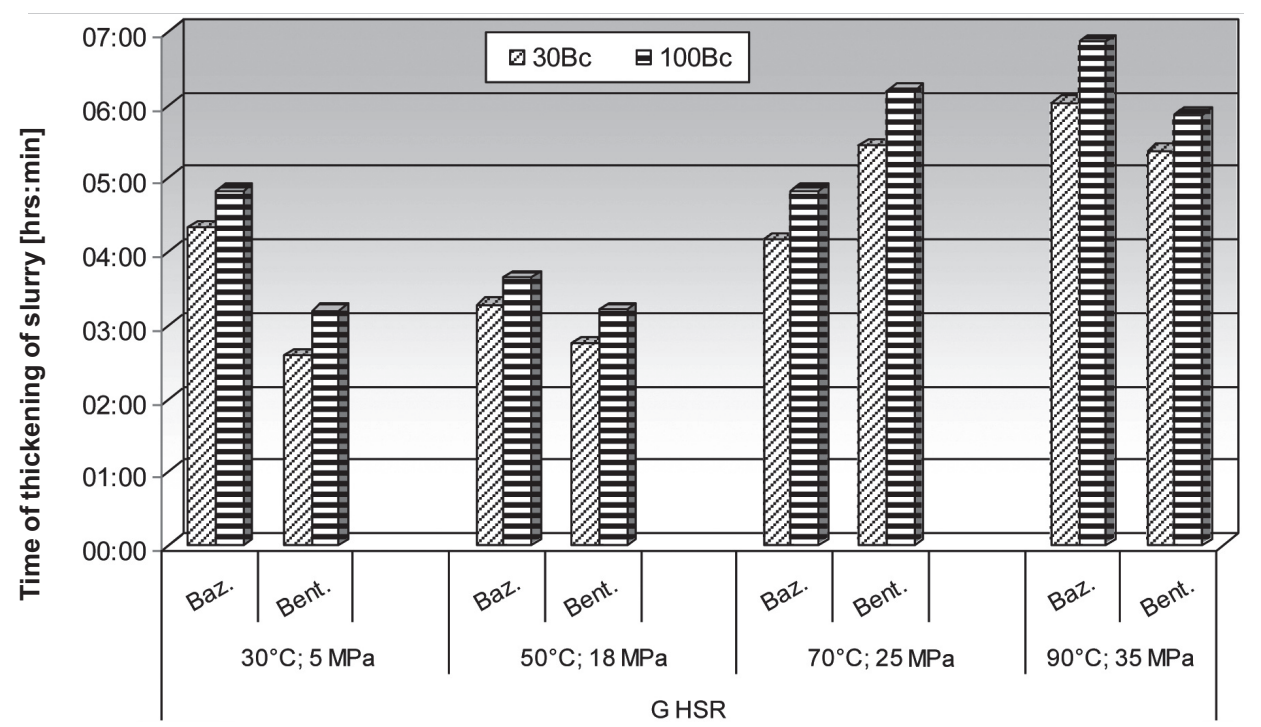

Fig. 6. Parameters of thickening time of cement slurry

The rheological parameters are compared in Figure 7 and Table 3 to better visualize the differences taking place after the additives were used. The yield point described in the Hershel-Bulkley model visibly increases. Plastic viscosity in the Casson model was observed to lower in slurries 2 and 4 in temperatures $30^{\circ} \mathrm{C}$ and $50^{\circ} \mathrm{C}$. The Casson viscosity tends to increase in bentonite-modified slurries Nos. 6 and 8, designed for sealing casing at temperatures $70^{\circ} \mathrm{C}$ and $90^{\circ} \mathrm{C}$. This can be connected with the use of large quantities of defoamer, i.e. $0.4 \%$ bwoc and $0.5 \%$ bwoc for slurries in temp. $70^{\circ} \mathrm{C}$ and $90^{\circ} \mathrm{C}$, as compared to $0.3 \%$ bwow of defoamer in slurries at temp. $30^{\circ} \mathrm{C}$ and $50^{\circ} \mathrm{C}$.

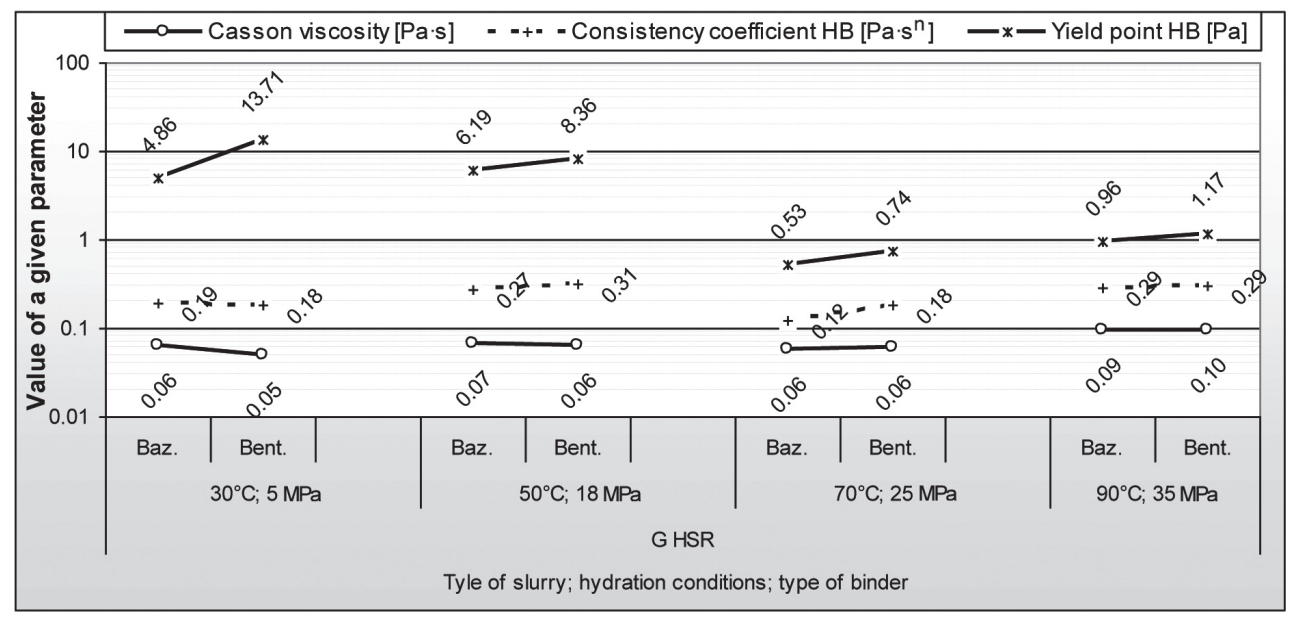

Fig. 7. Results of analyses of rheological parameters of cement slurries 
Table 3

Rheological parameters of cement slurries

\begin{tabular}{|c|c|c|c|c|c|c|c|c|c|}
\hline \multirow{2}{*}{$\begin{array}{l}\text { Rheolo- } \\
\text { gical } \\
\text { model }\end{array}$} & \multirow{2}{*}{$\begin{array}{c}\text { Rheolo- } \\
\text { gical } \\
\text { parameters }\end{array}$} & \multicolumn{8}{|c|}{ Slurry No. } \\
\hline & & 1 & 2 & 3 & 4 & 5 & 6 & 7 & 8 \\
\hline \multirow{2}{*}{$\begin{array}{l}\text { Newton } \\
\text { model }\end{array}$} & $\begin{array}{c}\text { Dynamic } \\
\text { viscosity } \\
{[\mathrm{Pa} \cdot \mathrm{s}]}\end{array}$ & 0.0998 & 0.1168 & 0.1100 & 0.1165 & 0.0673 & 0.0729 & 0.1125 & 0.1152 \\
\hline & $\begin{array}{c}\text { Correlation } \\
\text { coefficient } \\
{[-]} \\
\end{array}$ & 0.9861 & 0.9410 & 0.9775 & 0.9660 & 0.9974 & 0.9942 & 0.9939 & 0.9938 \\
\hline \multirow{3}{*}{$\begin{array}{c}\text { Bingham } \\
\text { model }\end{array}$} & $\begin{array}{c}\text { Plastic } \\
\text { viscosity } \\
{[\mathrm{Pa} \cdot \mathrm{s}]}\end{array}$ & 0.0899 & 0.0947 & 0.0966 & 0.0994 & 0.0647 & 0.0689 & 0.1063 & 0.1086 \\
\hline & $\begin{array}{l}\text { Yield point } \\
{[\mathrm{Pa}]}\end{array}$ & 6.9568 & 15.6283 & 9.4213 & 12.0442 & 1.8117 & 2.8498 & 4.4093 & 4.6330 \\
\hline & $\begin{array}{c}\text { Correlation } \\
\text { coefficient } \\
{[-]}\end{array}$ & 0.9985 & 0.9989 & 0.9973 & 0.9968 & 0.9990 & 0.9979 & 0.9975 & 0.9976 \\
\hline \multirow{3}{*}{$\begin{array}{c}\text { Ostwald- } \\
\text { de Waele } \\
\text { model }\end{array}$} & $\begin{array}{c}\text { Consistency } \\
\text { coefficient } \\
{\left[\mathrm{Pa} \cdot \mathrm{s}^{\mathrm{n}}\right]}\end{array}$ & 2.0184 & 6.8483 & 2.7547 & 3.9319 & 0.2593 & 0.4115 & 0.5591 & 0.6102 \\
\hline & $\begin{array}{c}\text { Exponent } \\
{[-]}\end{array}$ & 0.5263 & 0.3611 & 0.4952 & 0.4493 & 0.7894 & 0.7306 & 0.7524 & 0.7425 \\
\hline & $\begin{array}{c}\text { Correlation } \\
\text { coefficient } \\
{[-]}\end{array}$ & 0.9618 & 0.9298 & 0.9643 & 0.9591 & 0.9990 & 0.9934 & 0.9963 & 0.9957 \\
\hline \multirow{3}{*}{$\begin{array}{l}\text { Casson } \\
\text { model }\end{array}$} & $\begin{array}{c}\text { Casson } \\
\text { viscosity } \\
{[\mathrm{Pa} \cdot \mathrm{s}]}\end{array}$ & 0.0635 & 0.0504 & 0.0657 & 0.0630 & 0.0586 & 0.0602 & 0.0943 & 0.0954 \\
\hline & $\begin{array}{c}\text { Yield point } \\
{[\mathrm{Pa}]}\end{array}$ & 2.9038 & 9.5669 & 4.1373 & 5.9079 & 0.2450 & 0.9044 & 0.6961 & 0.7981 \\
\hline & $\begin{array}{c}\text { Correlation } \\
\text { coefficient } \\
{[-]}\end{array}$ & 0.9993 & 0.9962 & 0.9998 & 0.9997 & 0.9998 & 0.9994 & 0.9992 & 0.9993 \\
\hline \multirow{4}{*}{$\begin{array}{c}\text { Herschel- } \\
\text { Bulkley } \\
\text { model }\end{array}$} & $\begin{array}{c}\text { Yield point } \\
{[\mathrm{Pa}]}\end{array}$ & 4.8629 & 13.7108 & 6.1903 & 8.3565 & 0.5304 & 0.7428 & 0.9597 & 1.1676 \\
\hline & $\begin{array}{c}\text { Consistency } \\
\text { coefficient } \\
{\left[\mathrm{Pa} \cdot \mathrm{s}^{\mathrm{n}}\right]} \\
\end{array}$ & 0.1914 & 0.1842 & 0.2734 & 0.3099 & 0.1242 & 0.1803 & 0.2929 & 0.2948 \\
\hline & $\begin{array}{c}\text { Exponent } \\
{[-]}\end{array}$ & 0.8916 & 0.9045 & 0.8509 & 0.8371 & 0.9064 & 0.8620 & 0.8547 & 0.8568 \\
\hline & $\begin{array}{c}\text { Correlation } \\
\text { coefficient } \\
{[-]}\end{array}$ & 0.9999 & 1.0000 & 1.0000 & 1.0000 & 1.0000 & 1.0000 & 1.0000 & 1.0000 \\
\hline
\end{tabular}


While defining the influence of bentonite addition on mechanical parameters of hardened cement slurries, there were performed compressive strength tests, tests for adhesiveness to steel pipes, and adhesiveness to the rock formation (reference sandstone sample). Additionally, bentonite addition was analyzed for its impact on the porosity and permeability of samples. The obtained results are listed in Table 4, where improved parameters are marked in gray, and compared with the reference samples.

Table 4

Parameters of hardened cement slurries

\begin{tabular}{|c|c|c|c|c|c|c|c|c|c|c|c|c|c|}
\hline \multirow{4}{*}{ 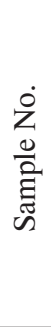 } & \multirow{4}{*}{ 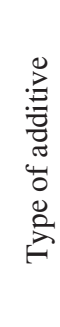 } & \multirow{4}{*}{ 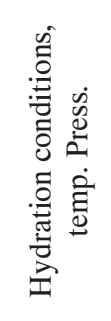 } & \multicolumn{11}{|c|}{ Analyzed parameter of hardened slurry } \\
\hline & & & \multicolumn{3}{|c|}{$\begin{array}{c}\text { Compressive } \\
\text { strength } \\
{[\mathrm{MPa}]}\end{array}$} & \multicolumn{3}{|c|}{$\begin{array}{c}\text { Adhesiveness } \\
\text { to steel pipes } \\
{[\mathrm{MPa}]}\end{array}$} & \multicolumn{3}{|c|}{$\begin{array}{c}\text { Adhesiveness } \\
\text { to rock } \\
{[\mathrm{MPa}]}\end{array}$} & $\begin{array}{c}\text { Perme- } \\
\text { ability } \\
{[\mathrm{mD}]}\end{array}$ & $\begin{array}{c}\text { Poro- } \\
\text { sity } \\
{[\%]}\end{array}$ \\
\hline & & & \multicolumn{11}{|c|}{ Hydration time } \\
\hline & & & $\begin{array}{c}2 \\
\text { days }\end{array}$ & $\begin{array}{c}7 \\
\text { days }\end{array}$ & $\begin{array}{c}28 \\
\text { days }\end{array}$ & $\begin{array}{c}2 \\
\text { days }\end{array}$ & $\begin{array}{c}7 \\
\text { days }\end{array}$ & $\begin{array}{c}28 \\
\text { days }\end{array}$ & $\begin{array}{c}2 \\
\text { days }\end{array}$ & $\begin{array}{c}7 \\
\text { days }\end{array}$ & $\begin{array}{c}28 \\
\text { days }\end{array}$ & \multicolumn{2}{|c|}{28 days } \\
\hline 1 & baz. & \multirow{2}{*}{$\begin{array}{c}30^{\circ} \mathrm{C} \\
5 \mathrm{MPa}\end{array}$} & 9.3 & 11.6 & 13.0 & 6.2 & 7.5 & 8.7 & 2.16 & 2.64 & 2.95 & 0.12 & 37.15 \\
\hline 2 & ben. & & 9.8 & 11.9 & 12.6 & 5.0 & 5.5 & 6.5 & 2.23 & 2.71 & 3.42 & 0.16 & 36.22 \\
\hline 3 & baz. & \multirow{2}{*}{$\begin{array}{c}50^{\circ} \mathrm{C} \\
18 \mathrm{MPa}\end{array}$} & 9.3 & 12.3 & 12.7 & 6.2 & 7.8 & 8.5 & 2.11 & 2.81 & 3.04 & 0.14 & 36.92 \\
\hline 4 & ben. & & 11.3 & 12.4 & 12.7 & 6.9 & 6.5 & 7.3 & 2.57 & 2.94 & 3.61 & 0.08 & 35.67 \\
\hline 5 & baz. & \multirow{2}{*}{$\begin{array}{c}70^{\circ} \mathrm{C} \\
25 \mathrm{MPa}\end{array}$} & 9.7 & 10.6 & 12.5 & 6.2 & 7.4 & 7.9 & 2.11 & 2.51 & 2.78 & 0.18 & 37.01 \\
\hline 6 & ben. & & 9.8 & 12.0 & 12.7 & 5.2 & 5.6 & 6.7 & 2.32 & 2.81 & 3.46 & 0.11 & 35.81 \\
\hline 7 & baz. & \multirow{2}{*}{$\begin{array}{c}90^{\circ} \mathrm{C} \\
35 \mathrm{MPa}\end{array}$} & 10.7 & 12.8 & 13.6 & 6.7 & 8.2 & 9.0 & 2.22 & 2.93 & 3.28 & 0.09 & 34.21 \\
\hline 8 & ben. & & 12.4 & 13.2 & 13.8 & 7.4 & 7.8 & 8.4 & 2.91 & 3.32 & 4.14 & 0.05 & 33.27 \\
\hline
\end{tabular}

The analysis of the obtained results revealed that the compressive strength slightly increased in the initial period ( 2 days and 7 days) of hydration of samples in wellbore conditions at a temperature of $30^{\circ} \mathrm{C}$ and $50^{\circ} \mathrm{C}$ and pressure $5 \mathrm{MPa}$ and $18 \mathrm{MPa}$. In the final period of hydration of 28 days (for above conditions), the compressive strength of hardened slurry No. 2 with bentonite addition was slightly lower than in the reference sample (Tab. 4), whereas in the case of sample No. 4 the compressive strength remained unchanged as compared to the reference sample. The increase of compressive strength after all periods of hydration was obtained after adding bentonite to sample No. 6, containing more water, and in sample No. 8. Such a behavior in the case of sample No. 6 can be a result of increased water demand of bentonite, which was outbalanced in this recipe by the water/cement ratio equal to 0.57 . The increase of compressive strength in sample No. 8 
modified with bentonite can be connected with the hydration temperature and pressure equal to $90^{\circ} \mathrm{C}$ and $35 \mathrm{MPa}$, respectively. These values are listed in Table 4 .

The analysis of adhesiveness to steel pipes for bentonite-modified slurries showed deterioration of parameters. A slight increase was obtained only for recipes Nos 4 and 8, for temp. $50^{\circ}$ and $90^{\circ} \mathrm{C}$, after two days of hydration of hardened slurry. The adhesiveness of hardened slurry to rock was improved for samples after all periods of hydration (highlighted in Table 4).

The use of bentonite to slurry resulted in a considerable lowering of permeability for gas and lowering of porosity of sample (Tab. 4). This can be explained by the sealing operation of the filler, i.e. bentonite, and higher viscosity of working fluid, preventing possible anisotropy of cement sheath.

There was observed a positive influence of bentonite mainly on the parameters of liquid slurry. This manifests itself in a slight increase of rheological parameters, mainly the yield point, thanks to which the slurry particles of various weight do not undergo fractionation under external forces. Such a behavior of bentonite is important when designing recipes of slurries to be used for sealing horizontal and directional wells, in which the sedimentation effect is one of the most important parameters defining the usability of a slurry recipe. A certain synergy was observed of bentonite and calcium chloride used to accelerate the time of bonding. The cooperation of bentonite and $\mathrm{CaCl}_{2}$ manifests itself by lowered water settling and filtration, which may be connected with the hydrophilic activity of bentonite and hygroscopic activity of calcium chloride. The water settling and filtration of slurry increase in the course of modification of slurries without calcium chloride. Attention should be paid to the fact that bentonite may shorten the time of thickening.

The analysis of hardened cement slurries revealed that bentonite had an advantageous influence on the adhesiveness of cement sheath to rock. However, this should be treated with caution due to the diversified mineral and petrophysical composition of the drilled rocks. The use of bentonite resulted in improved parameters describing microstructure of the cement sheath. The permeability for gas and porosity were lowered, which is very advantageous, when aiming at a maximally compact and impermeable surface of cement sheath.

\section{CONCLUSIONS}

The analysis of the influence of bentonite on the parameters of fresh and hardened cement slurry revealed that:

1. Introduction of bentonite to the recipe of cement slurry containing various additives and admixtures should be analyzed in detail for a given composition.

2. Bentonite causes slight lowering of slurry density in the case of recipes of relatively low water/cement ratio. 
3. Bentonite added to working water increases the viscosity, which consequently contributes to the sedimentation stability of the obtained cement slurry. The recipes of slurries with bentonite do not undergo fractionation under the gravity forces.

4. As a rule, bentonite should lower the settling and filtration in the case of non-complicated slurries containing cement and water. If bentonite is added to drilling slurries composed of numerous additives and admixtures, a reverse effect can be observed, i.e. secretion of a small quantity of water on the surface of slurry and a slight growth of filtration.

5. The presence of bentonite may shorten the time of thickening of slurry while performing measurements in the HTHP consistometer.

6. The analysis of mechanical parameters of cement slurries with bentonite addition revealed a slight lowering of compressive strength (after 28 days of hydration) in the case of slurries prepared for temperatures $30^{\circ} \mathrm{C}$ and $50^{\circ} \mathrm{C}$ and adhesiveness to steel pipes; the adhesiveness of cement stone and the rock increased.

7. The use of bentonite in cement slurries results in sealing up of the cement matrix, i.e. lower porosity and permeability for gas of the hardened slurry.

\section{REFERENCES}

[1] Aguilera R. et al.: Horizontal Wells. Gulf publishing Company, Houston 1991.

[2] Armessen P., Jourdan A., Mariotti Ch.: Horizontal drilling gas negative and positive factors. PennWell Publishing Comp. 1988.

[3] Bandrowski J., Merta H., Zioło J.: Sedymentacja zawiesin. Zasady i projektowanie. Wydawnictwo Politechniki Śląskiej, Gliwice 1995.

[4] Bhatty J.I., Banfill P.F.G.: Sedimentation behaviour in cement pastes subjected to continuous shear in rotational viscometers. Cement and Concrete Research, 1982.

[5] Chatterji S.: On the properties of freshly made Portland cement paste. Part 2. Sedimentation and strength of flocculation. Cement and Concrete Research, 1988.

[6] Hurlbut C.S.: Dana's Manual of Mineralogy. John Wiley and Sons, New York 1971.

[7] Kremieniewski M., Stryczek S., Kotwica Ł.: Zmiany w mikrostrukturze płaszcza cementowego w zależności od warunków hydratacji zaczynu. Nafta-Gaz, nr 12, 2014, pp. 918-926.

[8] Kremieniewski M., Rzepka M., Stryczek S., Wiśniowski R., Kotwica Ł., Złotkowski A.: Korelacja przepuszczalności i parametrów opisujących strukturę stwardniałych zaczynów cementowych stosowanych do uszczelniania otworów w rejonie Basenu Pomorskiego. Nafta-Gaz, nr 10, 2015, pp. 737-746.

[9] Kremieniewski M.: Ograniczenie ekshalacji gazu w otworach wiertniczych poprzez modyfikację receptur oraz ksztattowanie się struktury stwardniałych zaczynów uszczelniających. Prace Instytutu Nafty i Gazu - Państwowego Instytutu Badawczego, nr 199, Kraków 2016. 
[10] McNaught A.D., Wilkinson A.: IUPAC. Compendium of Chemical Terminology (Gold Book). 2nd ed. Blackwell Scientific Publications, Oxford 1997. Internet version: Nic M., Jirat J., Kosata B.: Colloidal dispersion (Eng.), actualization: A. Jenkins. DOI: 10.1351/goldbook.C01174.

[11] Nelson E.B. et al.: Well Cementing. Schlumberger Educational Service, Houston, Texas, USA, 1990.

[12] Rzepka M., Stryczek S.: Laboratoryjne metody określania parametrów technologicznych świeżych zaczynów uszczelniajacych przed zabiegiem zwiazanym $z$ procesem uszczelniania kolumn rur okładzinowych $w$ otworach wiertniczych. Wiertnictwo, Nafta, Gaz, vol. 25, No. 2, 2008, pp. 625-636.

[13] Stryczek S., Wiśniowski R., Gonet A., Złotkowski A.: The influence of time of rheological parameters of fresh cement slurries. AGH Drilling, Oil, Gas, 31, 2014, pp. $123-133$.

[14] Stryczek S., Gonet A., Wiśniowski R.: Wptyw wybranego dodatku mineralnego na własności technologiczne zaczynów cementowych. Wiertnictwo, Nafta, Gaz, 22/1, 2005.

[15] Stryczek S., Gonet A., Wiśniowski R., Złotkowski A.: Zaczyny uszczelniające do wypetniania pustek w górotworze solnym. Wiertnictwo, Nafta, Gaz, vol. 28, No. 1-2, 2011, pp. 391-400.

[16] Stryczek S., Gonet A., Wiśniowski R., Złotkowski A:. Badania świeżych zaczynów cementowych $z$ dodatkiem grafitu. Wiertnictwo, Nafta, Gaz, vol. 28, No. 4, 2011, pp. 749-756.

[17] Zima G.: Nowy rodzaj płuczki wiertniczej do zastosowania w warunkach HTHP. Nafta-Gaz, nr 8, 2015, pp. 556-564.

[18] Rzeczpospolita tupkowa. Studium wiedzy o gazie z formacji tupkowych. Prace INiG, nr 183, Kraków 2012. 